This article was downloaded by:

On: 3 July 2009

Access details: Access Details: Free Access

Publisher Routledge

Informa Ltd Registered in England and Wales Registered Number: 1072954 Registered office: Mortimer House, 37-41 Mortimer Street, London W1T 3JH, UK

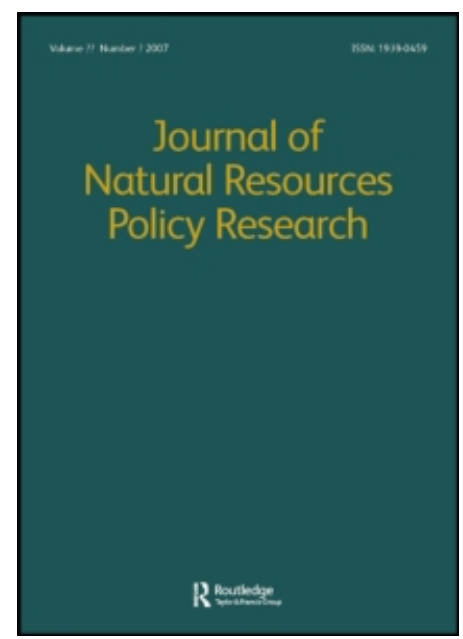

Journal of Natural Resources Policy Research

Publication details, including instructions for authors and subscription information: http://www.informaworld.com/smpp/title content=t780786795

\title{
The Core Challenges of Moving Beyond Garrett Hardin
}

Xavier Basurto ab; Elinor Ostrom ${ }^{\text {a }}$

a Workshop in Political Theory and Policy Analysis, Indiana University, Bloomington, IN, USA ${ }^{\mathrm{b}}$ Duke Marine

Lab, Nicholas School of the Environment, Duke University, Beaufort, NC, USA

Online Publication Date: 01 July 2009

To cite this Article Basurto, Xavier and Ostrom, Elinor(2009)'The Core Challenges of Moving Beyond Garrett Hardin',Journal of Natural Resources Policy Research, 1:3,255 - 259

To link to this Article: DOI: $10.1080 / 19390450903040447$

URL: http://dx.doi.org/10.1080/19390450903040447

\section{PLEASE SCROLL DOWN FOR ARTICLE}

Full terms and conditions of use: http://www.informaworld.com/terms-and-conditions-of-access.pdf

This article may be used for research, teaching and private study purposes. Any substantial or systematic reproduction, re-distribution, re-selling, loan or sub-licensing, systematic supply or distribution in any form to anyone is expressly forbidden.

The publisher does not give any warranty express or implied or make any representation that the contents will be complete or accurate or up to date. The accuracy of any instructions, formulae and drug doses should be independently verified with primary sources. The publisher shall not be liable for any loss, actions, claims, proceedings, demand or costs or damages whatsoever or howsoever caused arising directly or indirectly in connection with or arising out of the use of this material. 


\title{
The Core Challenges of Moving Beyond Garrett Hardin
}

\author{
XAVIER BASURTO**** \& ELINOR OSTROM* \\ *Workshop in Political Theory and Policy Analysis, Indiana University, Bloomington, IN, USA; **Duke \\ Marine Lab, Nicholas School of the Environment, Duke University, Beaufort, NC, USA
}

Hardin's theory-depicting a set of pastoralists inexorably trapped in the overuse of their common pasture - was thought for many years to be typical for common-pool resources (CPRs) not owned privately or by a government. Since Hardin thought the users would be 'trapped' in their tragic overuse of a resource, he advocated two solutions to prevent future tragedies: state control or individual ownership. We need to move beyond this simplistic approach, but face challenges in doing so.

In efforts to move beyond Hardin, it is important that one does not dismiss his predictions for some CPRs. The major problem of his original analysis was that he presented 'the tragedy' as a universal phenomenon. Field settings do exist where Hardin is correct. Overharvesting frequently occurs when resource users are totally anonymous, do not have a foundation of trust and reciprocity, cannot communicate, and have no established rules. In an experimental lab, subjects presented with a common-pool resource problem overharvest when they do not know who is in their group, no feedback is provided on individual actions, and they cannot communicate. They do worse than game theory predicts and fit the behaviour predicted by Hardin (Ostrom et al., 1994).

If the subjects are enabled to sit in a circle talking about the puzzle in a face-to-face group, however, they usually develop trust and reciprocity. Within a few rounds, they reduce overharvesting substantially and do very well (Ostrom et al., 1992). In traditional, non-cooperative game theory, communication is not supposed to improve the outcomes obtained, but many groups solve the problem of overharvesting after engaging in face-to-face communication. Further, many smaller groups that use CPRs-inshore fisheries, forests, irrigation systems, and pastures-have developed a diversity of norms and rules that have enabled them to solve problems of overharvesting (NRC, 1986, 2002; McCay \& Acheson, 1987; Berkes, 1989; McKean, 1992; Baland \& Platteau, 1996; Dolšak \& Ostrom, 2003; Basurto, 2005; Lansing, 2006; van Laerhoven \& Ostrom, 2007).

Correspondence Address: Xavier Basurto, Workshop in Political Theory and Policy Analysis, Indiana University, 513 N. Park Avenue, Bloomington, IN 47408-3895, USA. Email: xbasurto@ indiana.edu

ISSN 1939-0459 Print/1939-0467 Online (C) 2009 Taylor \& Francis

DOI: $10.1080 / 19390450903040447$ 
To move beyond Hardin's tragedy of the commons, we need to avoid falling into either of two analytical and policy traps: (1) deriving and recommending policy blueprints or 'panaceas'; or (2) asserting 'my case is unique'. The first trap is caused, to some extent, by the ease with which simple, powerful models can be translated into overarching generalizations, which has led to policy blueprints abounding in the literature. Fisheries, for instance, are rich with examples advocating individual transferable quotas (ITQs), marine protected areas (MPAs), and community-based management (CBM) as cure-alls (Degnbol et al., 2006).

Governing CPRs like fisheries is challenging. CPRs are normally used by multiple individuals generating finite quantities of resource units where one person's use subtracts from the quantity of resource units available to others. Most CPRs are sufficiently large that multiple actors can simultaneously use the resource system, and excluding potential beneficiaries is costly. We need to build a theoretical foundation for explaining why some resource users are able to self-organize and govern the use of a resource over time in a sustainable manner and why others fail or never make the effort. To build theory, it is necessary to move away from both extremes to develop an interdisciplinary diagnostic framework that helps to provide a foundation for further empirical research and learning (Agrawal, 2008; Bardhan \& Ray, 2008; Chopra, 2008).

\section{The Panacea Analytical Trap}

Historically, the cure-alls that have been recommended most frequently promote government ownership (Ophuls, 1973; Feeny et al., 1996, p. 195) or privatization (Demsetz, 1967; Posner, 1977; Simmons et al., 1996). Panacea-type solutions can be a by-product of approaches that generate highly abstract models and use simple empirical studies to illustrate general patterns of social phenomena (Bouchaud, 2008). For instance, since the important early studies of open-access fisheries by Gordon (1954) and Scott (1955), most theoretical studies by political economists have analyzed simple CPR systems using relatively similar assumptions (Feeny et al., 1996; Ruddle, 2007; Ruddle \& Hickey, 2008). In such systems, it is assumed that the resource generates a highly predictable, finite supply of one type of resource unit (one species, for example) in each relevant time period. Resource users are assumed to be homogeneous in terms of their assets, skills, discount rates, and cultural views. Users are also assumed to be short-term, profit-maximizing actors who possess complete information. As a result, this theory universally assumes that anyone can enter the resource and harvest resource units. Users are viewed as able to gain property rights only to what they harvest, which they then sell in an open competitive market. Under this approach, the open-access condition is a given. The users make no effort to change it. Users act independently and do not communicate or coordinate their activities in any way.

This approach emphasizes collecting information on a large number of cases to be able to find the correlation of dependent and independent variables with a statistical degree of significance. This can come at the cost of being able to develop in-depth knowledge of each of the cases under study. Homogenization assumptions about the cases under consideration are often necessary to conduct quantitative analyses. In the process, the analyst risks losing track of the importance of context and history and faces challenges to be able to effectively convey the sense of complexity and diversity that exists in the empirical world. 
The basic theory was applied to all CPRs, regardless of the capacity of resource users to communicate and coordinate their activities, until the work of the National Academy of Sciences' Panel on Common Property (NRC, 1986) strongly challenged this approach. The growing evidence from many qualitative studies of CPRs conducted in the field called for a serious rethinking of the theoretical foundations for the analysis of CPRs (Berkes et al., 1989; McCay \& Acheson, 1987).

\section{'My-Case-is-Unique' Analytical Trap}

The rich case-study literature has played a prominent role in illustrating the wide diversity of settings in which appropriators dependent on CPRs have organized themselves to achieve much higher outcomes than is predicted by the conventional theory (Wade, 1994; Ruddle \& Johannes, 1985; Sengupta, 1991). In being able to tap into the rich case-study literature, however, we also need to move beyond the argument that each resource system, and the people who use it, is unique. At one level, that assertion is true. All humans are unique and all human organizations are unique as well. The problem comes from assuming that there are no commonalities across cases that can be the foundation for theoretical analysis, explanations, and diagnosis. Ecologists have long dealt with complex systems that at one level are unique (e.g. individual species), but are also able to move outward to larger systems (e.g. populations or ecosystems) and find commonalities among different species and behaviours. Medical diagnosis of illness and potential remedies is feasible, even though each individual is unique.

Often, the scholarly treatment of social phenomena as unique is the by-product of training scholars in a research strategy that focuses first on understanding the complexity of social phenomena. Qualitative-oriented scholars, such as ethnographers and historians, are usually associated with this approach. Students of this tradition are often interested in understanding how different elements fit together to constitute a case. They examine many parts and attempt to construct a representation from the interconnections among the aspects of each case. In order to be able to do so, it is necessary to acquire in-depth knowledge about the instances under study.

Often, the goal of this research approach is to describe how different aspects constitute the case as a whole, which may then be compared and contrasted with other cases. Given the depth of data that scholars amass about each aspect of their case, qualitative scholars frequently work with one or a few cases at a time. Because of their familiarity with the complexity and in-depth understanding of the particularities of the instances that characterize certain phenomena, qualitative scholars tend to avoid making generalizations about their findings. Sometimes it is precisely the rarity of certain social phenomena, characterized by only one, two, or a handful of instances, that might attract a scholar's attention and curiosity to them in the first place (Ragin, 2000, 2008).

\section{In Closing}

To move beyond Hardin's theory, we need to draw on both general theory related to causal processes and learn how to identify key variables present or absent in particular settings, so as to understand successes and failures. We agree that to build a diagnostic theory, it is important to incorporate contextual factors into policy analyses. We also need to avoid falling into the presumption that all individual settings are so different from one 
another that all we can do is describe the intricate detail of particular settings. Those of us who study institutions and human behaviour, while trying to develop theoretical understanding, do realize that every case, as well as all human beings, is unique. On the other hand, while we have a unique combination of factors affecting our personalities, behaviour, and actions, all humans share some attributes. It is always a challenge to determine which of those attributes are important at any one time. This is what the medical profession has been struggling to do for many eras. The great contribution of medical sciences is the development of diagnostic theory that enables medicine to move beyond panaceas. Policy sciences need to work toward the development of a diagnostic theory of the commons.

\section{Acknowledgements}

The authors wish to acknowledge essential financial support from the National Science Foundation (Grant \# BCS0601320) and from the Workshop in Political Theory and Policy Analysis at Indiana University, as well as the excellent editing of Patty Lezotte. This paper draws in part on a longer invited feature forthcoming in Economia delle fonti di energia e dell'ambiente, titled 'Beyond the Tragedy of the Commons'.

\section{References}

Agrawal, A. (2008) Sustainable governance of common-pool resources: Context, method and politics, in: P. Bardhan \& I. Ray (Eds) The Contested Commons: Conversations Between Economists and Anthropologists, pp. 46-65 (Oxford: Blackwell).

Baland, J.-M., \& Platteau, J.-P. (1996) Halting Degradation of Natural Resources: Is There a Role for Rural Communities? (Oxford: Clarendon Press).

Bardhan, P., \& Ray, I. (2008) The Contested Commons: Conversations Between Economists and Anthropologists (Oxford: Blackwell)

Basurto, X. (2005) How locally designed access and use controls can prevent the tragedy of the commons in a Mexican small-scale fishing community, Society and Natural Resources, 18 (7), pp. 643-659.

Berkes, F. (Ed) (1989) Common Property Resources: Ecology and Community-Based Sustainable Development (London: Belhaven Press).

Berkes, F., Feeny, D., McCay, B. J., \& Acheson, J. M. (1989) The benefits of the commons, Nature, 340 (6229), pp. 91-93.

Bouchaud, J. P. (2008) Economics needs a scientific revolution, Nature, 455 (30), p. 1181.

Chopra, K. (2008) Commentary 4: Disciplinary perspectives and policy design for common-pool resources, in: P. Bardhan \& I. Ray (Eds) The Contested Commons: Conversations Between Economists and Anthropologists, pp. 248-256 (Oxford: Blackwell).

Degnbol, P., Gislason, H., Hanna, S., Jentoft, S., Raakjær Nielsen, J., Sverdrup-Jensen, S., Wilson, D. C.. (2006) Painting the floor with a hammer: technical fixes in fisheries management, Marine Policy, 30 (5), pp. 534-543.

Demsetz, H. (1967) Toward a theory of property rights, American Economic Review, 57 (2), pp. 347-359.

Dolšak, N., \& Ostrom, E. (Eds) (2003) The Commons in the New Millennium: Challenges and Adaptations (Cambridge, MA: MIT Press).

Feeny, D., Hanna, S. S., \& McEvoy, A.F. (1996) Questioning the assumptions of the 'tragedy of the commons' model of fisheries, Land Economics, 72, pp. 187-205.

Gordon, H. S. (1954) The economic theory of a common property resource: The fishery, Journal of Political Economy, 62 (2), pp. 124-142.

van Laerhoven, F., \& Ostrom, E. (2007) Traditions and trends in the study of the commons, International Journal of the Commons, 1 (1), pp. 3-28.

Lansing, J. S. (2006) Perfect Order: Recognizing Complexity in Bali (Princeton, NJ: Princeton University Press).

McCay, B. J., \& Acheson, J. M. (1987) The Question of the Commons: The Culture and Ecology of Communal Resources (Tucson: University of Arizona Press).

McKean, M. A. (1992) Success on the commons: A comparative examination of institutions for common property resource management, Journal of Theoretical Politics, 4 (3), pp. 247-281. 
NRC (National Research Council) (1986) Proceedings of the Conference on Common Property Resource Management (Washington, DC: National Academy Press).

NRC (National Research Council) (2002) The Drama of the Commons, E. Ostrom, T. Dietz, N. Dolšak, P. Stern, S. Stonich \& E. Weber. (Eds). Committee on the Human Dimensions of Global Change (Washington, DC: National Academy Press).

Ophuls, W. (1973) Leviathan or oblivion, in: H. E. Daly (Ed) Toward a Steady State Economy, pp. 215-230 (San Francisco: Freeman).

Ostrom, E., Gardner, R., \& Walker, J. (1994) Rules, Games, and Common-Pool Resources (Ann Arbor: University of Michigan Press).

Ostrom, E., Walker, J., \& Gardner, R. (1992) Covenants with and without a sword: Self-governance is possible, American Political Science Review, 86 (2), pp. 404-417.

Posner, R. A. (1977) Economic Analysis of Law, 2nd ed. (Boston: Little, Brown).

Ragin, C. C. (2000) Fuzzy-Sets Social Science (Chicago: University of Chicago Press).

Ragin, C. C. (2008) Redesigning Social Inquiry: Fuzzy Sets and Beyond (Chicago: University of Chicago Press). Ruddle, K. (2007) Misconceptions, outright prejudice, Samudra Report, No. 48, pp. 4-9.

Ruddle, K., \& Hickey, F. R. (2008) Accounting for the mismanagement of tropical nearshore fisheries, Environment, Development, and Sustainability, 10 (5), pp. 565-589.

Ruddle, K., \& Johannes, R. E. (Eds) (1985) The Traditional Knowledge and Management of Coastal Systems in Asia and the Pacific (Jakarta: UNESCO).

Scott, A. D. (1955) The fishery: The objectives of sole ownership, Journal of Political Economy, 63 (2), pp. 116-124.

Sengupta, N. (1991) Managing Common Property: Irrigation in India and the Philippines (New Delhi: Sage).

Simmons, R. T., Smith Jr., F. L., \& Georgia, P. (1996) The Tragedy of the Commons Revisited: Politics Versus Private Property (Washington, DC: Center for Private Conservation).

Wade, R. (1994) Village Republics: Economic Conditions for Collective Action in South India (San Francisco: ICS Press). 